\title{
THE INFLUENCE OF JOB INVOLVEMENT AND JOB SATISFACTION TOWARD TURNOVER INTENTION ON EMPLOYEES OF PT. GLOBAL NIKEL MULTIGUNA TANGERANG
}

\author{
LITA HAIRIAH \\ Accounting on MCN Group \\ litahairiah23@gmail.com \\ Roni Faslah \\ Fakultas Ekonomi Universitas Negeri Jakarta \\ ronifaslah@feunj.ac.id
}

\begin{abstract}
This research aims to determine whether there is influence between job involvement and job satisfaction toward turnover intention on employees of PT. Global Nikel Multiguna. This research was carried out for 3 months, started from February to May 2015. The method used is a survey method. The population in this research were all employees of PT. GLOBAL NIKEL MULTIGUNA, amounting 85 employees and researchers took samples used as many as 68 employees by using random sampling technique. The instrument used of obtain data on the variables $X_{1}$ (Job Involvement), $X_{2}$ (Job Satitisfaction), and $Y$ (Turnover Intention) was measured using questionnaire with Likert scale for $X_{1}$ and $Y$, and using semantic differentials for $X_{2}$. Then the data was tested for the validity and reliability, analysis through multiple regression techniques and classical assumption. The hypothesis was tested with significant the margin of error of 0.05 using t-test and analysis of variance (ANOVA). The results showed siginificant relationship between job involvement and job satisfaction on turnover intention of employees with regression equation $\hat{Y}=122.353-0.561 X_{1}-0.198 X_{2}$. from the analysis of data, obtaining

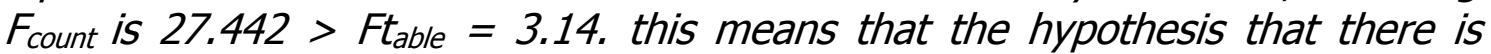
significant relationship between job involvement and job satisfaction on turnover intention ef employees received. Meanwhile, the coefficient of determination for $R^{2}$ is $45.8 \%$ while remaining $54.2 \%$ is influence by other factors not examined. Based on the above results, it is advisable for the leader of the company to give freedom of speech to the employees and provide corresponds salary whose contribute in the company in order to surpress levels of turnover intention on employees at the company.
\end{abstract}

Keyword: Job Involvement, Job Satisfaction and Turnover Intention 


\section{PENDAHULUAN}

Meskipun karyawan adalah aset penting perusahaan, namun terkadang perusahaan tidak memperhatikan karyawan secara penuh. Karyawan biasanya dianggap sebagai alat produksi. Perusahaan lebih terfokus pada upaya pencapaian target produksi dan target lainnya dalam jangka pendek. Hal ini mengakibatkan perusahaan menjadikan karyawannya seperti mesin. Sangat disayangkan jika mesin tersebut tidak dirawat atau diperlakukan dengan baik yang berdampak akan menimbulkan kejenuhan atau ketidakcocokan pada diri karyawan sehingga akan menstimulasi munculnya keinginan berpindah atau turnover intention.

Keluar dari tempat kerja atau berpindah kerja (turnover) merupakan salah satu pilihan jika seorang karyawan sudah merasa tidak cocok dengan apa yang diharapkan di tempat kerjanya. Turnover sebagai akibat dari keinginan berpindah (turnover intention) bagi karyawan dipilih karena berharap ingin memperbaiki keadaan dari sisi psikologis maupun karir masa depan yang lebih baik, namun dari sisi perusahaan pergantian karyawan (turnover) yang tinggi akan menimbulkan dampak negatif, seperti menciptakan ketidakstabilan terhadap kondisi tenaga kerja dan peningkatan biaya sumber daya manusia. Hal tersebut menjadikan organisasi dalam perusahaan tidak efektif karena kehilangan karyawan yang berpenga- laman dan perlu melatih kembali karyawan baru.

Turnover intention harus disikapi sebagai suatu fenomena dan perilaku manusia yang penting dalam kehidupan perusahaan dari sudut pandang individu maupun sosial, mengingat bahwa keinginan berpindah karyawan tersebut akan mempunyai dampak yang signifikan bagi perusahaan dan karyawan yang bersangkutan. Saat ini, tingginya tingkat turnover intention telah menjadi masalah yang serius bagi perusahaan, bahkan beberapa perusahaan mengalami frustasi ketika mengetahui proses rekrutmen yang telah berhasil menjaring karyawan yang berkualitas pada akhirnya menjadi sia-sia karena staf yang direkrut tersebut telah memilih pekerjaan di perusahaan lain.

Fenomena turnover intention dialami pula oleh PT. Global Nikel Multiguna yang bergerak di bidang jasa nikel chrome \& electroplating di Indonesia, seperti plating komponen sepeda, otomotif, alat-alat mekanik, rumah tangga (kompor), dan lainnya. Ini terlihat jelas dari data perusahaan mengenai keadaan karyawan mereka 3 tahun belakangan adalah sebagai berikut:

Bagan 1. Data Turnover Karyawan PT. Global Nikel Multiguna 20122014 


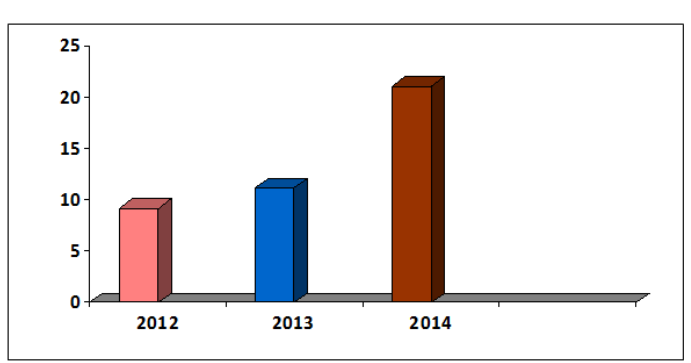

Data diolah peneliti

Berdasarkan bagan tersebut, terlihat bahwa jumlah turnover karyawan PT. Global Nikel Multiguna selama tiga tahun terakhir semakin meningkat, yaitu dari 9,2\% pada tahun 2012 menjadi $21,1 \%$ pada tahun 2014. Tingginya tingkat turnover pada karyawan merupakan suatu masalah yang dihadapi oleh perusahaan PT. Global Nikel Multiguna.

Banyak faktor mempengaruhi keinginan berpindah dari perusahaan (turnover intention) pada diri karyawan, diantaranya adalah ketidakamanan kerja, pengembangan karir, kepuasan kerja, dan keterlibatan kerja pada karyawan yang rendah.

Faktor yang menyebabkan seorang karyawan memiliki keinginan untuk meninggalkan perusahaan adalah karena kepuasan kerja. Kepuasan kerja disini meliputi gaji atau kompensasi yang diperoleh dari perusahaan, kepuasan terhadap jabatan, pekerjaan yang dikerjakan, hubungan dengan lingkungan kerja, dan kesempatan-kesempatan yang ada di perusahaan. Untuk dapat melaksanakan kerjanya dengan baik tentunya karyawan harus merasakan perasaan puas dari imbalan maupun sarana penunjang dari perusahaan yang dapat memacu pelaksanaan kerjanya. Apabila perusahaan dapat memberikan kepuasan kerja yang tinggi kepada karyawan maka akan menerima hasil yang baik seperti meningkatnya produktivitas perusahaan, meningkatnya kesetiaan dan loyalitas, serta rendahnya keinginan berpindah (turnover intention) pada karyawan. Banyak perusahaan yang tidak menyadari pentingnya memberikan kepuasan kerja kepada karyawan. Ketidakpuasan tersebut menimbulkan turnover intention yang tinggi dikalangan karyawan, terutama karyawan dengan kinerja tinggi dan memiliki keahlian yang lebih. Hal itu tentu saja merupakan kerugian yang sangat besar bagi perusahaan, karena perusahaan harus mencari pengganti karyawan tersebut.

Faktor berikut yang turut mempengaruhi keinginan berpindah (turnover intention) adalah keterlibatan kerja yang merupakan identifikasi seseorang secara psikologis terhadap pekerjaannya, berpartisipasi aktif, dan pekerjaan dianggap sebagai bahan yang penting dalam kehidupan individu. Namun, banyak masalah yang dihadapi oleh perusahaan seperti adanya keterlibatan kerja yang rendah pada diri karyawan sehingga dapat mengakibatkan tingginya keinginan berpindah (turnover intention) pada karyawan. Banyak perusahaan yang tidak menyadari pentingnya memberikan kesempatan karyawan untuk terlibat dalam organisasi, misal- 
nya seperti keterlibatan dalam pengambilan keputusan atau kesempatan untuk menyumbangkan ide yang ada di pikirannya, hal ini dapat memicu rasa motivasi yang rendah karena merasa tidak ada kesempatan untuk berkembang, sehingga tidak dapat membantu memuaskan kebutuhan seorang karyawan akan tanggung jawab, prestasi, pengakuan, dan peningkatan harga diri.

Berdasarkan latar belakang masalah yang telah diuraikan, maka permasalahan penelitian dapat dirumuskan sebagai berikut :

1. Apakah keterlibatan kerja berpengaruh terhadap keinginan berpindah pada karyawan PT. Global Nikel Multiguna Tangerang?

2. Apakah kepuasan kerja berpengaruh terhadap keinginan berpindah pada karyawan PT. Global Nikel Multiguna Tangerang?

3. Apakah keterlibatan kerja dan kepuasan kerja berpengaruh terhadap keinginan berpindah pada karyawan PT. Global Nikel Multiguna Tangerang?

\section{KAJIAN PUSTAKA \\ Keinginan Berpindah (Turnover Intention)}

Turnover intention merupakan suatu masalah yang sering terjadi pada perusahaan, tingkat turnover karyawan yang tinggi pada perusahaan merupakan ukuran yang sering digunakan sebagai indikasi adanya masalah yang mendasar pada perusahaan. Intensi merupakan indikasi seberapa keras seseorang berusaha atau seberapa banyak usaha yang dilakukan untuk menampilkan suatu perilaku. Semakin keras intensi seseorang untuk terlibat dalam suatu perilaku, semakin besar kecenderungan ia untuk benar-benar melakukan perilaku tersebut.

Menurut Robert L. Mathis (Jackson, 2001) dalam bukunya Mana-jemen Sumber Daya Manusia yang diterjemahkan oleh Jimmy Sadeli menyatakan bahwa turnover adalah tingkat keluar masuk karyawan yang terjadi ketika karyawan meninggal-kan organisasi dan harus digantikan.

Sedangkan menurut Robbins (Judge, 2008) menjelaskan, turnover is the voluntary and involuntary withdrawal from an organization. Turnover adalah pengunduran diri permanen secara sukarela maupun tidak sukarela dari suatu organisasi.

Hal ini menjelasakan bahwa turnover merupakan adanya tindakan perpindahan karyawan dari suatu organisasi ke organisasi lain karena keputusan karyawan itu sendiri ataupun keadaan organisasi yang tidak sesuai lagi dengan harapan karyawannya, perpindahan dapat dilakukan secara sukarela dan tidak sukarela.

Menurut God et al., (Js, 2004), keinginan berpindah adalah kecenderungan atau keingin-an (intention) seseorang untuk secara 
aktual berpindah (turnover) dari suatu organisasi. Keinginan berpindah yaitu segenap pikiran yang muncul dari pikiran seorang karyawan yang secara aktual dapat diwujudkan menjadi nyata niat/ keinginan tersebut.

Hal tersebut dipertegas Sunjoyo (Muafi, 2008) dan Muafi, turnover intention didefi-nisikan sebagai intensi seseorang untuk melakukan pemisahan aktual (turnover) dari suatu organisasi.

Menurut Lyons (Habibullah, 2011) mendefinisikan, Turn-over intention sebagai kecende-rungan untuk meninggalkan organisasi/pekerjaan.

Turnover intention menjelaskan bahwa keinginan yang ada didalam diri karyawan untuk meninggalkan pekerjaannya, tetapi belum secara fakta dilakukan oleh karyawan tersebut. Keinginan berupa niat yang ada dipikiran seseorang untuk meninggalkan pekerjaan yang mereka jalani, tetapi hanya sekedar keinginan belum terealisasikan secara fakta untuk pindah dari perusahaan karena adanya pemikiran-pemikiran yang harus dipertimbangkan, seperti jika meninggalkan organisasi ini apakah ada perusahaan yang memberikan keuntungan lebih dari perusahaan tempat saya bekerja. Jadi, masih banyak yang dipikirkan lewat keinginan seseorang karyawan untuk meninggalkan perusahaan tempat bekerja.

Menurut Zeefan (Hanafiah, 2014) menyatakan bahwa turnover intention adalah kecenderungan atau niat karyawan untuk berhenti dari bekerja dan pekerjaannya secara sukarela menurut pemikirannya sendiri. Keinginan berhenti dari pekerjaan ini timbul berdasarkan pemikiran sendiri, keinginan sendiri, dan keputusan yang diambil secara sukarela tanpa dipaksa oleh pihak siapapun.

Sejalan dengan pendapat Zeefan, menurut Whitman (Liu, 2007) Turnover intention is the thoughts of the employee regarding voluntarily leaving the organization. Keinginan berpindah adalah pemikiran karyawan sehubungan dengan meninggalkan organisasi secara sukarela.

Hal ini bahwa keinginan berpindah muncul dari pemikiran karyawan untuk meninggalkan organisasi yang belum pasti, hanya berupa niat dan keinginan yang ada didalam pemikiran diri seorang karyawan untuk meninggalkan organisasi atau tempat kerja mereka. Keinginan meninggalkan organisasi disini bersifat sukarela bukan paksaan karena muncul dari hati, keinginan, dan pemikirannya sendiri.

Pendapat lain, menurut Suwandi dan Indriantoro (Arianto, 2001) menyatakan pendapatnya, Keinginan berpindah (turnover intention) mencerminkan keinginan individu untuk mening-galkan organisasi dan mencari alternatif pekerjaan. Keinginan yang timbul dari pemikiran seseorang karyawan untuk meninggalkan perusahaan 
atau mencari pekerjaan yang lebih baik, pekerjaan yang menjanjikan kehidupannya yang membuat seorang karyawan terse-but bangga akan pekerjaan yang mereka lakukan.

Sedangkan, Menurut Quarales (Mandasari, 2011)turnover intention adalah keinginan individu untuk meninggalkan organisasi dan mencari alternatif pekerjaan lain.

Menurut Veithzal Rivai (Rivai, 2005) menyatakan dalam bukunya Manajemen Sumber Daya Manusia, bahwa keinginan berpindah (turnover intention) adalah keinginan pekerja untuk berhenti dari perusahaan karena pindah ke perusahaan lain.

Dari ketiga definisi di atas, terlihat bahwa turnover intention merupakan niat yang mengacu pada aktifitas seseorang karyawan yang ingin berhenti dari perusahaan karena ingin pindah ke perusahaan lain dan mencari pekerjaan lain yang lebih menjanjikan.

Menurut Giebels dan Janssen (Cristian, 2005)berpendapat bahwa, turnover intention refers to an individual's intent to look actively for employ-ment elsewhere, and therefore may be considered a longterm coping strategy. Keinginan berpindah mengacu pada keinginan seseorang untuk secara aktif mencari kesempatan bekerja ditempat lain, oleh karena itu membutuhkan tahapan yang panjang untuk mencapainya.

Ratnawati dan Wijaya (Kusuma, 2002) berpendapat bahwa keinginan berpindah merupakan keinginan individu untuk meninggalkan perusahaan dan mencari alternatif pekerjaan lain. Keinginan untuk pindah mengacu pada hubungannya dengan organisasi dan belum diwujudkan dalam tindakan pasti meninggalkan organisasi.

Hal ini menegaskan bahwa mencari kesempatan lain mendorong karyawan memiliki keinginan yang timbul pada diri seseorang untuk adanya niat berkeinginan pindah. Walaupun membutuhkan waktu yang panjang untuk mendapatkannya, asalkan dapat memberikan apa yang menjadi harapan dan tujuan mereka. Dengan proses yang tidak mudah itu, terkadang menjadi bahan pemikiran yang cukup matang untuk menentukan keputusan karyawan apakah harus tetap atau meninggalkan keluar dari organisasi tersebut.

Lee dan Moudy (Sulistyawati, 2008) mengungkapkan, pengukuran keinginan berpindah dapat ditinjau dari dua aspek, yaitu:

1. Adanya pikiran untuk keluar, seseorang merasa tidak betah terhadap tempat dia bekerja akan mempunyai keinginan untuk segera meninggalkan atau keluar dari organisasi tempat kerjanya

2. Tersedia alternatif pekerjaan lain, dengan tersedianya pekerjaan ditempat lain membukakan perasaan untuk mencari alternatif pekerjaan di tempat lain atau adanya tempat yang lebih 
menjanjikan kepada seseorang sehingga mengumpulkan informasi-informasi dalam mendapatkan pekerjaan yang lebih baik.

Keinginan berpindah muncul karena adanya proses berpikir seseorang individu dengan mempertimbangkan kesempatan pekerjaan ditempat lain, karena rasa tidak nyaman atau rasa tidak puas akan pekerjaannya namun belum direalisasikan dalam tindakan yang nyata. Keinginan ini mungkin saja tidak tercapai, jika karyawan berubah pikiran dan merasa ia harus tetap berada di organisasi tersebut. Hal ini juga dapat dilihat dari karyawan yang memiiliki komitmen yang tinggi dan setia terhadap pekerjaannya, terlihat lebih berdedikasi dibandingkan dengan karyawan yang tidak memiliki rasa cinta dan loyal terhadap pekerjaan dan perusahaannya.

\section{Keterlibatan Kerja}

Karyawan sebagai roda perusahaan harus diperhatikan perkembangannya sehingga selalu mendapatkan hasil yang optimal. Salah satu cara untuk meningkatkan kualitas kerja karyawan adalah dengan keterlibatan kerja, karena keterlibatan kerja menyangkut masalah keaktifan berpartisipasi dalam pekerjaan dan menganggap kinerja yang karyawan lakukan penting yang pada akhirnya akan berdampak pada kinerjanya.

Stephen Robbins (Judge, Perilaku Organi-sasi, 2008)dalam bukunya yang berjudul Perilaku
Organisasi mengatakan, keterlibatan kerja adalah derajat dimana orang dikenal dari pekerjaanya, berpartisipasi aktif didalamnya, dan menganggap prestasinya penting untuk harga diri.

Stephen Robbins dan Mary Coulter (Robbins, 2007) dalam buku Manajemen mengatakan bahwa keterlibatan kerja adalah tingkat pengidentifikasian karyawan dengan pekerjaannya, secara aktif berpar-tisipasi dalam pekerjaannya, dan menganggap kinerja di pekerjaan-nya adalah penting untuk kebaikan dirinya sendiri.

Dengan demikian dapat diartikan bahwa keterlibatan kerja adalah partisipasi aktif yang dilakukan karyawan dalam melaksanakan pekerjaannya, dan karyawan menganggap penting pekerjaan yang mereka lakukan bermanfaat untuk dirinya sendiri.

Sejalan dengan pendapat Stephen dan Mary, menurut Sahlan Asnawi (Arifuddin, 2002) mengatakan, keterlibatan kerja didefinisikan sebagai partisipasi secara aktif dalam melaksanakan suatu pekerjaan serta rasa tanggung jawab terhadap pekerjaannya. Dipertegas oleh Istijanto (Istijanto, 2005), keterlibatan kerja didefinisikan sebagai adanya pengenalan terhadap pekerjaan sendiri, dan partisipasi secara aktif dalam pengambilan keputusan.

Definisi di atas dapat menjelaskan bahwa keterlibatan kerja merupakan tingkatan dimana seseorang mengidentifikasikan dirinya 
terhadap pekerjaannya dengan cara berpartisipasi aktif dalam melaksanakan pekerjaannya dan ikut serta dalam hal pengambilan keputusan. Dapat dinyatakan bahwa aktif berpartisipasi dalam pekerjaan dapat menunjukkan seorang pekerja terlibat dalam pekerjaan. Aktif partisipasi adalah perhatian seseorang terhadap sesuatu. Dari aktif berpartisipasi dapat dilihat seorang karyawan yang perhatian, peduli, dan menguasai bidang pekerjaannya.

Menurut Indira dan Ashari (Januarti, 2006) menyatakan bahwa, salah satu cara yang dapat dipakai untuk memancing keterlibatan kerja pe-gawai adalah dengan memancing partisipasi mereka dalam berbagai kesempatan pembuatan keputusan. Individu yang terlibat dalam pekerjaan adalah individu yang selalu memikirkan pekerjaannya, menekuni pekerjaannya, dan membuka kesempatan untuk mengekspresikan diri dengan tempatnya bekerja. Partisipasi aktif ini tidak hanya berkaitan dengan hal fisik semata, tetapi juga partisipasi dengan keterlibatan mental dan emosional. Keterlibatan dalah hal membuat keputusan mengenai perusahaan, akan memancing keaktifan karyawan tersebut. Dengan partisipasi dan diajak untuk membicarakan permasalahan yang ada diperusahaan, karyawan akan lebih merasa dihargai di dalam kantor. Karyawan akan lebih semangat terlibat di perusahaan tersebut dan justru akan meningkatkan kinerjanya.

Stephen Robbins dan Timothy Judge (Judge, Perilaku Organi-sasi, 2008) menyatakan, ke-terlibatan kerja diartikan sebagai suatu ukuran sampai dimana individu secara psikologis memihak pekerjaan mereka dan menganggap penting tingkat kinerja yang dicapai sebagai penghargaan diri.

Demikian pula dengan Timothy Judge, Elloy (Arifuddin, 2002) mengungkapkan, keterlibatan kerja didefinisikan sebagai adanya kepedulian untuk menyelesaikan pekerjaannya dengan baik serta memihak pekerjaannya.

Dari kedua definisi di atas dapat dijelaskan bahwa keterlibatan kerja adalah tingkat sampai dimana individu memihak pekerjaan mereka. Memihak pekerjaan disini dapat diartikan dengan seberapa jauh karyawan peduli terhadap pekerjaannya dan akan melakukan apa saja sesuai dengan kemampuannya untuk dapat menyelesaikan tugas-tugasnya.

Indira Januarti dan Ashari Bunyanudin (Januarti, 2006) menyatakan bahwa keterlibatan kerja bagaimana mengukur tingkat sejauh mana individu memihak pekerjaan yang dilakukan dan benar-benar peduli dengan jenis kerja itu. Karyawan dengan tingkat keterlibatan kerja yang tinggi dengan kuat memihak pada jenis kerja yang dilakukan yaitu benarbenar peduli dengan jenis kerja itu, misalnya 
menyumbangkan ide untuk kemajuan perusahaan, dengan senang hati memenuhi peraturan-peraturan perusahaan dan mendukung kebijakan perusahaan, dan lain-lain.

Berdasarkan pendapat tersebut, dapat dijelaskan bahwa keterlibatan kerja adalah derajat dimana seseorang memihak pekerjaannya. Keterlibatan kerja penting untuk harga diri seorang karyawan, karena jika karyawan memiliki keterlibatan kerja yang tinggi maka karyawan akan merasa dihargai. Selain itu, seseorang memiliki keterlibatan kerja yang tinggi dapat dilihat dari sejauh mana ia memihak pekerjaannya. Semakin tinggi keterlibatan kerja semakin tinggi pula tingkat kepedulian karyawan terhadap tugas-tugasnya dan begitupun sebaliknya. Hal ini tercermin dari sumbangan ide untuk kemajuan perusahaan, mentaati peraturan perusahaan, dan mendukung kebijakan perusahaan.

Disinilah bagaimana peran pegawai dalam mengidentifikasi tugas dan wewenangnya dalam pengerjaan tugas yang mereka peroleh, nilai baik atau tidaknya karyawan dapat dinilai seberapa berperannya karyawan dalam menyelesaikan tugas tersebut. Lebih dari itu karyawan yang terlibat dalam penyelesaian tugas cenderung membuat karyawan akan semangat kerja. Seseorang yang tidak bersungguh-sungguh melibatkan dirinya pada pekerjaan menunjukkan bahwa pekerjaan bukan aspek penting dalam hidupnya.
Adanya rasa keterlibatan kerja bukan hanya saja sekedar rasa senang terhadap pekerjaannya melainkan menciptakan rasa turut memiliki terhadap pekerjaannya. Selain itu, menimbulkan rasa untuk mawas diri, bekerja lebih baik, dan tentu untuk menghasilkan produk yang lebih bermutu.

Individu yang terlibat pada pekerjaan memiliki ciri-ciri yang dikemukakan oleh Robbins (Judge, Perilaku Organi-sasi, 2008)sebagai berikut:

1. Individu menempatkan kerja sebagai perhatian utama dalam kehidupannya

2. Individu berpartisipasi aktif dalam pekerjaannya

3. Individu menganggap kinerja sebagai pusat harga diri

4. Individu menganggap ada konsistensi antara kinerja dengan harga diri.

Karyawan yang terlibat dalam pekerjaan adalah individu yang selalu memikirkan pekerjaannya, dan membuka kesempatan untuk mengekspresikan dirinya. Partisipasi karyawan berarti keterlibatan kerja dalam pekerjaan secara mental dan emosional bukan hanya soal fisik saja. Karyawan melihat kinerja sebagai pusat harga diri, maksudnya adalah individu akan berusaha memberikan yang terbaik dari apa yang dikerjakannya karena hasil kerja inilah yang meningkatkan harga diri. Bagi karyawan, kinerja menentukan arah dari pekerjaannya. 


\section{Kepuasan Kerja}

Kepuasan kerja merupakan salah satu faktor penting bagi setiap perusahaan, dimana dalam hal ini kepuasan kerja diukur bagaimana perusahaan memperlakukan setiap karyawannya. Istilah kepuasan merujuk pada sikap umum seorang individu terhadap pekerjaannya. Setiap orang yang bekerja mengharapkan memperoleh kepuasan dari tempatnya bekerja. Pada dasarnya kepuasan kerja merupakan hal yang bersifat individual karena setiap individu akan memiliki tingkat kepuasan yang berbedabeda sesuai dengan nilai-nilai yang berlaku dalam diri setiap individu. Semakin banyak aspek dalam pekerjaan yang sesuai dengan keinginan individu, maka semakin tinggi tingkat kepuasan yang dirasakan.

Kepuasan kerja adalah keadaan emosional suatu perasaan yang menyongkong (mendukung) seseorang terhadap pekerjaannya. Sikap emosional yang menyenangkan penekanannya tentang sikap yang dilakukan oleh individu terhadap pekerjaannya. Sehingga individu tersebut dapat bekerja dengan semangat dan dapat memberikan distribusi yang optimal pada perusahaan. Hal ini sesuai dengan pendapat dari Keith Davis menyatakan bahwa job satisfaction is the favorableness with employee view their work. Kepuasan kerja adalah perasaan yang menyokong atau tidak menyokong yang dialami pekerja dalam bekerja (Anwar,
2005:117). Juga pendapat Wexley dan Yuki yang juga dikutip oleh Anwar Prabu menyatakan kepuasan kerja is the way an employee feels about his or her job. Kepuasan kerja adalah cara pegawai merasakan dirinya atau pekerjaannya (Anwar, 2005:117).

Kepuasan kerja merupakan perasaan yang dimiliki oleh seseorang terhadap pekerjaannya. Perasaan tersebut dapat menyenangkan dan tidak menyenangkan akan pekerjaan yang dimiliki karyawan. Perasaan seseorang karyawan yang menilai pekerjaannya, bagaimana pekerjaan tersebut membuat karyawan senang atau tidak senang, puas atau tidak puas, maupun suka atau tidak suka akan pekerjaan yang mereka jalani. Perasaan senang atau tidak senang dengan apa yang didapatkan di dalam perusahaan tempat bekerja, baik secara materil atau nonmateril. Materil seperti gaji, non materil seperti dukungan moral dari atasan ataupun rekan kerja. Hal ini sesuai dengan pendapat T. Hani Handoko (2011:193) yang mendefinisikan kepuasan kerja sebagai keadaan emosional yang menyenangkan atau tidak menyenangkan dengan mana karyawan memandang pekerjaan mereka. Kepuasan kerja mencerminkan perasaan seseorang terhadap pekerjaannya. Hal ini nampak dalam sikap positif karyawan terhadap pekerjaan dan segala sesuatu yang dihadapi di lingkungan kerjanya. 
Menurut Sondang P. Siagian (Anwar, 2000) dalam bukunya yang berjudul Manajemen Sumber Daya Manusia mengatakan, kepuasan kerja merupakan suatu cara pandang seseorang baik yang bersifat positif maupun yang bersifat negatif tentang pekerjaannya.

Stephen P. Robbins (Robbins, 2007) dalam bukunya menyatakan: job satisfaction refers to an individuals general attitude toward his or her job. A person in a high level of job satisfaction old positive attitude the job. A person who dissatisfied with his or her hold negative attitude toward about that job.

Pendapat tersebut memiliki makna, kepuasan kerja merujuk pada sikap umum terhadap pekerjannya. Seseorang dengan tingkat kepuasan yang tinggi, memiliki perasaan positif terhadap pekerjaannya. Sedangkan, orang dengan tingkat kepuasan kerja yang rendah memiliki perasaan negatif terhadap pekerjaannya.

Kepuasan kerja merupakan sikap (positif) seorang karyawan terhadap pekerjaannya. Hal tersebut merupakan hasil evaluasi terhadap karakteristik-karakteristik dari pekerjaannya yang timbul berdasarkan penilaian terhadap situasi kerja. Penilaian dilakukan sebagai rasa menghargai dalam mencapai salah satu nilai-nilai penting dalam pekerjaannya, apabila pekerjaannya tersebut menyenangkan, tentunya karyawan akan mempertahankan untuk dapat terus bekerja di perusahaan tersebut. Tetapi sebaliknya, apabila pekerjaannya tersebut dipandang tidak menyenangkan, tentu akan berdampak pada rendahnya kepuasan kerja karyawan dan timbul perasaan sikap negatif. Sehingga ketidakpuasan kerja yang mereka rasakan akan berdampak negatif bagi perusahaan, yaitu menurunnya kontribusi yang mereka berikan pada perusahaan.

Veithzal Rivai (Rivai, 2005) men-definisikan kepuasan kerja adalah penilaian dari pekerjaan tentang seberapa jauh pekerjaannya secara keseluruhan memuaskan kebutuh-annya.

Ini dimaksudkan bahwa kepuasan kerja merupakan suatu penilaian pekerjaan dimana dilihat seberapa jauh pekerjaan itu dapat memuaskan kebutuhannya.

Steve dan Thomas (2008:163) menyatakan, job satisfaction is generally defined as employees' feelings of affect toward their jobs situations. Kepuasan kerja secara umum didefinisikan sebagai perasaan dari afektif karyawan terhadap pekerjaan atau situasi pekerjaan. Dipertegas oleh Stephen dan Michael (West, 2010) yang mengung-kapkan, job satisfaction refers to a person's general feelings abaout their job. Kepuasan kerja mengacu pada perasaan umum seseorang tentang pekerjaan mereka.

Kepuasan kerja merupakan perasaan umum seseorang terhadap pekerjaan atau situasi pekerjaan yang mereka hadapi ditempat kerja 
yang menetukan mereka bahagia atau tidaknya.

Inti dari tingkat kepuasan kerja seseorang adalah menentukan perasaan puas atau tidak puas akan kerjanya dilihat sejauh mana pekerjaan yang dilakukan seseorang tersebut, membuat mereka merasakan bahagia atau tidak, puas atau tidak, nyaman atau tidak, pantas atau tidak terhadap pekerjaan yang mereka miliki.

Kepuasan Kerja memiliki beberapa dimensi. Dimensi-dimensi tersebut merupakan hal-hal yang menentukan tingkat kepuasan kerja seseorang terhadap pekerjaannya. Selanjutnya para ahli mendeskripsikan dimensi-dimensi dari kepuasan kerja.

Menurut Mathis dan John $\mathrm{H}$. Jackson (Jackson, 2001), Dimensions of job satisfaction frequently mention-ed include work, pay, promotion opportunities, supervision, and co-workers. Dapat diartikan, dimensi kepuasan kerja sering disebutkan termasuk pekerjaan, gaji, kesem-patan promosi, pengawasan, dan rekan kerja. Debra L. Nelson dan James Campebell Quick (Quick, 2011) mengungkapkan, job satisfaction have five specific dimentions of the job: pay, the work it self, promotion opportunities, supervision and co workers. Dapat diartikan, kepuasan kerja memiliki lima dimensi spesifik dari pekerjaan: gaji, pekerjaan itu sendiri, kesempatan promosi, supervisi dan rekan kerja.
Menurut Luthans (Sopiah, 2008) yang menjelaskan lima dimensi kepuasan kerja, antara lain:

1. Pekerjaan itu sendiri, dalam hal pekerjaan yang memberikan tugas menarik, kesempatan untuk belajar, dan kesempatan untuk menerima tanggung jawab.

2. Gaji atau upah, sejumlah upah yang diterima dan tingkat yang menunjukkan hal ini bisa dipandang sebagai hal yang dianggap pantas dibandingkan dengan orang lain dalam organisasi.

3. Kesempatan promosi, kesempatan untuk maju dalam organisasi.

4. Pengawasan, kemampuan supervisor untuk memberikan bantuan teknis dan dukungan moral

5. Rekan sekerja, tingkat yang menunjukkan rekan kerja pandai secara teknis dan mendukung secara sosial.

Menurut Robbins dan Judge (Judge, Perilaku Organi-sasi, 2008)terdapat 5 faktor yang menentukan kepuasan kerja seorang karyawan, dianataranya adalah:

1. Pekerjaan itu sendiri

2. Gaji

3. Promosi

4. Pengawasan

5. Rekan Kerja

Sedangkan, menurut M. Ivancevich et,al. (Ivancevich et, 2006) kepuasan kerja dihasilkan dari persepsi mereka mengenai 
pekerjaan mereka dan tingkat kesesuaian antara individu dan organisasi. Beberapa faktor yang penting adalah:

1. Pekerjaan itu sendiri, sejauh mana pekerjaan dianggap menarik, menyediakan kesempatan untuk belajar, dan memberikan tanggung jawab.

2. Imbalan gaji, jumlah pembayaran yang diterima dan tingkat kesesuaian antara tingkat pembayaran dengan pekerjaan yang dilakukan.

3. Peluang promosi, kesediaan peluang untuk maju

4. Supervisi, kompetensi teknis dan keterampilan interpersonal dari atasan langsung.

5. Rekan kerja, sejauh mana rekan kerja bersahabat, kompeten, dan memberikan dukungan.

6. Kondisi pekerjaan, sejauh mana lingkungan kerja fisik memberikan kenyamanan dan mendukung produktivitas.

7. Keamanan pekerjaan, keyakinan bahwa posisi seseorang relatif aman dan ada peluang untuk dapat terus bekerja dalam organisasi.

Dengan demikian, untuk mengukur kepuasan kerja seseorang dapat melalui dimensi kepuasan kerja yaitu pekerjaan itu sendiri yang diberikan oleh seseorang untuk belajar dan kesempatan utnuk menerima tanggung jawab, gaji atau upah yang diterima oleh karyawan dari perusahaan, kesempatan promosi yang diberikan oleh karyawan untuk maju dalam organisasi, pengawasan yang dilakukan atasan untuk memastikan suatu proses pekerjaan dilakukan dengan sesuai prosedur yang berlaku oleh bawahannya, dan rekan kerja yang memberikan dukungan dan kenyamanan bekerja.

\section{Pengaruh Keterlibatan Kerja Terhadap Keinginan Berpindah (Turnover Intention).}

Keterlibatan kerja berhubungan kuat dengan turnover intention pada diri karyawan. Karyawan yang memiliki tingkat keterlibatan kerja yang kuat dengan pekerjaannya, tentu akan sering masuk kerja, dan sangat sedikit kemungkinan untuk berkeinginan pindah ke perusahaan lain. Karyawan akan setia dan bersemangat dengan pekerjaan serta perusahaannya. Karyawan akan rajin masuk, dan tidak berkeinginan untuk pindah ke perusahaan lain karena mencintai pekerjaan yang mereka lakukan. Keinginan berpindah (turnover intention) pada hakikatnya merupakan keinginan atau niat karyawan untuk keluar dari perusahaan dan mencari alternatif pekerjaan yang lebih baik. Karyawan dengan niatan seperti itu tentu didahului dengan pemikiran-pemikiran positif dan negatif, jika ia benar-benar ingin keluar dari perusahaan. Keinginan yang bersifat sukarela dari karyawan itu sendiri dan perusahaan berhak memutuskan keinginannya. Hal ini didukung oleh pendapat dari 
beberapa penulis dan hasil-hasil penelitian berikut ini.

Veithzal Rivai (Rivai,

Kepemimpinan dan Perilaku

Organisasi,, 2012)dalam buku

Kepemimpinan dan Perilaku

Organisasi mengatakan tingkat

keterlibatan kerja yang tinggi telah

ditemukan berkaitan dengan

kemangkiran yang lebih rendah dan

tingkat permohonan berhenti

(turnover intention) yang lebih rendah.

Veitzhal, Stephen Robbins dan Timothy mengatakan keterlibatan kerja yang tinggi berhubungan dengan ketidakhadir-an yang lebih sedikit dan angka pengunduran diri (turnover intention) yang lebih rendah. Robbins dan Coulter (Robbins, 2007) karyawan dengan tingkat keterli-batan kerja yang tinggi dengan kuat mengenali dan benar-benar mem-perhatikan jenis pekerjaan yang mereka lakukan, tingkat yang tinggi telah ditemukan terkait dengan tingkat absensi yang lebih sedikit dan tingkat pengunduran diri karyawan yang lebih rendah.

Teori-teori di atas didukung oleh penelitian Roni Faslah (Faslah, 2010) dalam jurnalnya yang mengatakan: adanya keterli-batan kerja yang rendah pada diri karyawan mengakibatkan tingginya tingkat keinginan berpindah pada karyawan. Karyawan beranggapan bahwa partisipasi mereka tidak terlalu dibutuhkan oleh perusahaan yang pada akhirnya tidak dapat membantu dalam pemuasan kebu- tuhan seorang karyawan akan tanggung jawab, prestasi, pengakuan, dan peningkatan harga diri.

Menurut Roni Faslah (Faslah, 2010) dalam jurnalnya, keterlibatan kerja yang rendah berpengaruh terhadap keinginan berpindah yang tinggi pada karyawan. Karyawan beranggapan dengan keterlibatan kerja seperti pengambilan keputusan yang rendah dan tidak terlalu dibutuhkan perusahan membuat karyawan beranggapan dirinya kurang dianggap penting diperusahaan tersebut, membuat karyawan kurang dipercaya mendapatkan tanggung jawab, dan pengakuan akan pekerjaannya. Karyawan berpikir partisipasi yang dilakukan diperusahaan tidak terlalu penting, yang membuat karyawan timbul pikiran untuk keluar dari perusahaan dan mencari tempat kerja lain yang dapat memenuhi kebutuhan mereka.

\section{Pengaruh Kepuasan Kerja Terhadap Keinginan Berpindah (Turnover Intention).}

Menurut Sondang (Sondang, 2008), salah satu penyebab timbulnya keinginan pindah kerja adalah ketidakpuasan pada tempat bekerja sekarang. Sebab ketidakpuasan itu beragam seperti penghasilan rendah atau dirasakan kurang memadai, kondisi kerja yang kurang memuas-kan, hubungan yang tidak serasi baik dengan atasan maupun dengan rekan sekerja, dan pekerjaan yang tidak sesuai. Hal ini dapat disimpulkan 
terdapat korelasi antara tingkat kepuasan kerja dengan kuat atau lemahnya keinginan berpindah kerja.

Pendapat tersebut menjelaskan ketidakpuasan karyawan cukup beragam, seperti penghasilan rendah atau kurang memadai, kondisi kerja kurang memuaskan, hubungan tidak serasi dengan rekan kerja, dan pekerjaan tidak sesuai. Dengan beragamnya ketidakpuasan karyawan, dapat menimbulkan indikasi turnover intention pada diri karyawan. Sehingga dapat dilihat, tingkat kepuasan kerja berpengaruh terhadap kuat atau lemahnya keinginan seorang karyawan untuk pindah dari tempatnya bekerja.

Stephen P. Robbins dan Mary Coulter (Robbins, 2007) mengatakan karyawan yang tidak puas memiliki tingkat perputaran karyawan (turnover intention) yang lebih tinggi. Tingkat kepuasan tidak menjadi elemen penting dalam memprediksi tingkat perputaran karyawan di kalangan karyawan yang berkinerja bagus karena organisasi biasanya melakukan apapun untuk mempertahankan mereka (kenaikan gaji, pujian, dan peluang promosi besar).

Handoko (Handoko, 2011) menga-takan kepuasan kerja mempenga-ruhi tingkat perputaran karyawan (turnover) dan absensi. Hal tersebut sejalan dengan pendapat Wahyu Saidi dan Supandi Halim (Saidi, 2007), kepuasan kerja digambarkan dengan korelasi secara negatif dengan turnover intention, dengan korelasi lebih tinggi dari pada korelasi kepuasan dengan absensi.

Kepuasan kerja memiliki hubungan dengan keinginan berpindah. Orang yang merasakan puas terhadap pekerjaannnya tentu saja akan bertahan di perusahaan dan tidak memiliki keinginan untuk berpindah. Sedangkan, karyawan yang tidak puas akan pekerjaannya akan berniat untuk pindah dari pekerjaan yang mereka lakukan dengan melakukan indikasi kesalahan seperti mereka datang tidak tepat waktu ataupun absen dalam pekerjaannya. Pernyataan ini juga diperkuat oleh pendapat: Lijan Poltak Sinambela (Sinambela, 2012) dalam bukunya mengatakan kepuasan kerja berpengaruh secara negatif dengan keinginan keluar masuknya (turnover intention) para pegawai.

\section{Keterlibatan Kerja Dan Kepu- Asan Kerja Berpengaruh Negatif Terhadap Keinginan Berpindah (Turnover Intention)}

Simanjuntak (Simanjuntak,
2013), me-ngatakan Kurangnya
kesempatan promosi, pekerjaan
yang kurang menantang, kondisi
kerja yang tidak sesuai dengan
karyawan, gaji, dan keterlibatan
kerja karyawan yang rendah,
ketidakpuasan pada kar-yawan,
karyawan menganggap bahwa
dirinya tidak terlalu penting bagi
perusahaan, sehingga kar-yawan
berniat untuk pindah ke tempat
pekerjaan lain. Hal ini menjelaskan


ketidakpuasan karya-wan seperti kurangnya kesempatan promosi, pekerjaan kurang menan-tang, kondisi kerja dan gaji yang tidak sesuai, tingkat keterlibatan kerja karyawan yang rendah, karyawan tidak puas dengan pekerjaannya dan karyawan berang-gapan dirinya tidak terlalu dipentingkan di perusahaan, akan memicu karyawan untuk berke-inginan meninggalkan perusahaan dan mencari pekerjaan lain yang lebih menjanjikan.

Didukung oleh Roni Faslah (Faslah, 2010), mengemukakan faktor penyebab terjadinya turnover intention pada diri karyawan, diantaranya adalah komitmen organisasi, ketidakamanan kerja, kinerja karyawan, stres kerja, pengembangan karir, kepuasan kerja, dan keterlibatan kerja pada karyawan yang rendah.

Naomei Simanjuntak dan Edy Rahardja (2013:8) menunjukkan keterlibatan kerja dan kepuasan kerja berpengaruh negatif dan signifikan terhadap turnover intention. Semakin tinggi keterlibatan kerja dan kepuasan kerja karyawan maka akan semakin rendah keinginan berpindah (turnover intention) pada diri karyawan.

Dapat diartikan, keterlibatan kerja dan kepuasan kerja pada karyawan menghasilkan reaksi seperti keinginan untuk keluar (turnover intention) dari suatu pekerjaan. Semakin tinggi keterlibatan kerja dan kepuasan kerja seorang karyawan di dalam perusahaan tentu saja semakin rendah keinginan berpindah karyawan tersebut, ataupun sebaliknya. Karyawan yang sangat terlibat akan pekerjaannya akan memihak pekerjaannya, akan berpartisipasi untuk mencintai pekerjaan, dan orang yang memiliki kepuasan di dalam perusahaan tentu akan merasakan perasaan puas terhadap pekerjaan yang dimilikinya. Karyawan tersebut akan melakukan kebaikan, peningkatan kinerja, rajin masuk, tidak pernah terlambat, tidak pernah melanggar aturan, sehingga tidak muncul keinginan untuk pindah dari perusahaan. Ataupun sebaliknya, kurang terlibat dan tidak puas dengan pekerjaan maka keinginan berpindah karyawan tersebut akan tinggi.

\section{METODE PENELITIAN}

Penelitian dilaksanakan pada PT. Global Nikel Multiguna yang dilakukan pada bulan Februari 2015 sampai dengan bulan Mei 2015. Metode penelitian yang digunakan dalam penelitian ini adalah metode survei. Metode survei adalah teknik riset dimana informasi dikumpulkan menggunakan penyebaran kuesioner (Darmawan W, 2005:22). Data yang digunakan adalah data primer untuk variabel bebas Keterlibatan Kerja (X1), variabel bebas Kepuasan Kerja (X2) dan variabel terikat Keinginan Berpindah (turnover intention) ( $\mathrm{Y})$.

Populasi dalam penelitian ini adalah seluruh karyawan PT. Global 
Nikel Multiguna Tangerang yang berjumlah 85 orang. Sedangkan sampel dalam penelitian ini sebanyak 68 orang. Pengambilan sampel didasarkan pada tabel Isaac dan Michae/ dengan taraf kesalahan 5\% (Sugiyono, 2006). Teknik pengambilan sampel menggunakan teknik acak proporsional (proportional random sampling). Teknik sampel acak proporsional (proportional random Sampling) artinya: sampel diwakili sesuai dengan perbandingan (proporsi) frekuensinya di dalam populasi keseluruhan (Sugiyono, 2006).

Teknik analisis data dilakukan dengan estimasi parameter model regresi. Pengolahan data dalam penelitian ini menggunakan program SPSS versi 17.0.

\section{HASIL PENELITIAN}

Tahapan dalam penelitian ini telah melaui uji persyaratan analisis yang meliputi uji normalitas, uji liniearitas regresi serta uji asumsi kelasik. Semua uji tersebut memenuhi persyaratan untuk dilakukan analisis inferensi. Sebelumnya didahuli dengan uji validitas dan reliabilitas instrumen penelitian. Dari kedua uji tersebut dapat dinyatakan bahwa butir-butir instrumen untuk mengukur variabel keterlibatan kerja, variabel kepuasan kerja dan variabel keinginan berpindah dikatakan valid dan reliabel dengan nilai reliabilitas variabel keterlibatan kerja $r_{11}=0,912$; variabel kepuasan kerja $r_{11}=0,917 ;$ dan variabel keinginan berpindah $r_{11}=0,911$.

Uji regresi dilakukan untuk mengetahui bagaimana suatu variabel mempengaruhi variabel lain. Rumus regresi linier berganda ini digunakan untuk mengetahui hubungan kuantitatif dari keterlibatan kerja $\left(X_{1)}\right.$ dan kepuasan kerja $\left(X_{2}\right)$ terhadap keinginan berpindah $(\mathrm{Y})$. Hasil perhitungan uji regresi berganda pada SPSS 17.0 adalah sebagai berikut:

Tabel 1. Uji Regresi Berganda

\begin{tabular}{|c|c|c|c|c|c|c|}
\hline \multirow{2}{*}{\multicolumn{2}{|c|}{ Model }} & \multicolumn{2}{|c|}{$\begin{array}{l}\text { Unstandardized } \\
\text { Coefficients }\end{array}$} & \multirow{2}{*}{$\begin{array}{c}\text { Standardized } \\
\text { Coefficients } \\
\text { Beta }\end{array}$} & \multirow[t]{2}{*}{$\mathrm{t}$} & \multirow[t]{2}{*}{ Sig. } \\
\hline & & B & Std. Error & & & \\
\hline \multirow[t]{3}{*}{1} & (Constant) & 122,353 & 13,717 & & 8,920 & ,000 \\
\hline & Keterlibatan Kerja &,- 561 & 078 &,- 665 & $-7,233$ & 000 \\
\hline & Kepuasan Kerja &,- 198 & 080 &,- 227 & $-2,468$ & 000 \\
\hline
\end{tabular}

Berdasarkan tabel di atas, diperoleh persamaan regresi berganda sebagai berikut: $\hat{Y}=122,353-0,561 X_{1}$ $0,198 X_{2}$
Pada tabel koefisien di atas, nilai konstanta sebesar 122,353, artinya jika keterlibatan kerja dan kepuasan kerja nilainya 0 , maka 
keinginan berpindah nilainya adalah 122,353 .

Nilai koefisien $\left(b_{1}\right)$ sebesar 0,561 artinya jika kepuasan kerja nilainya tetap dan keterlibatan kerja mengalami kenaikan 1 poin, maka keinginan berpindah akan mengalami penurunan sebesar 0,561 dengan asumsi variabel independen lain nilainya tetap. Koefisien bernilai negatif artinya terdapat hubungan negatif antara keterlibatan kerja dengan keinginan berpindah, semakin tinggi keterlibatan kerja maka akan semakin rendah keinginan berpindah pada karyawan.

Nilai koefisien $\left(b_{2}\right)$ sebesar 0,198 artinya jika keterlibatan kerja nilainya tetap dan kepuasan kerja mengalami kenaikan 1 poin, maka keinginan berpindah akan mengalami penurunan sebesar 0,198 dengan asumsi variabel independen lain nilainya tetap. Koefisien bernilai negatif artinya terdapat hubungan negatif antara kepuasan kerja dengan keinginan berpindah, semakin tinggi kepuasan kerja maka semakin rendah keinginan berpindah pada karyawan.

Uji F digunakan untuk mengetahui pengaruh variabel independen secara serentak terhadap variabel dependen, apakah pengaruhnya signifikan atau tidak. Kriteria pengambilan keputusan yaitu jika Fhitung $<\mathrm{F}_{\text {tabel, }}$ maka $\mathrm{H}_{0}$ diterima, artinya variabel keterlibatan kerja dan kepuasan kerja secara serentak tidak berpengaruh terhadap keinginan berpindah. Sedangkan jika $F_{\text {hitung }}>\mathrm{F}_{\text {tabel, }}$ maka $\mathrm{H}_{0}$ ditolak, artinya variabel $X_{1}$ dan $X_{2}$ secara serentak berpengaruh terhadap $\mathrm{Y}$. Berikut hasil perhitungan $\mathrm{Uji} F$ dengan menggunakan SPSS.

Tabel 2. Uji $F$

\begin{tabular}{|c|c|c|c|c|c|c|}
\hline \multicolumn{7}{|c|}{ ANOVA $^{a}$} \\
\hline & Model & Sum of Squares & Df & Mean Square & $\mathrm{F}$ & Sig. \\
\hline 1 & Regression & 2491,658 & 2 & 1245,829 & 27,442 &, $000^{\mathrm{b}}$ \\
\hline & Residual & 2950,857 & 65 & 45,398 & & \\
\hline & Total & 5442,515 & 67 & & & \\
\hline
\end{tabular}

a. Dependent Variable: Keinginan Berpindah

b. Predictors: (Constant), Kepuasan Kerja, Keterlibatan Kerja

Berdasarkan tabel di atas, Fhitung sebesar 27,442 sedangkan besarnya Ftabel dapat dilihat pada tabel statistik dengan signifikasi $5 \%$ atau 0,05, df1 (Jumlah variabel-1) atau 3-1 = 2, dan df2 = n-k-1 (n adalah jumlah data, dan $\mathrm{k}$ adalah jumlah variabel bebas) atau 68-3 = 65, maka diperoleh $F_{\text {tabel }}$ sebesar 3,14. Dengan demikian, Fhitung $27,442>3,14 \mathrm{~F}_{\text {tabel, }}$ maka $\mathrm{H}_{0}$ ditolak, sehingga dapat disimpulkan keterlibatan kerja dan kepuasan 
kerja secara serentak berpengaruh terhadap keinginan berpindah.

Uji T digunakan untuk mengetahui pengaruh variabel independen secara parsial terhadap variabel dependen yaitu apakah pengaruhnya signifikan atau tidak. Kriteria pengambilan keputusan yaitu jika -t hitung > -t tabel, maka $\mathrm{H}_{0}$ diterima, artinya variabel $X_{1}$ tidak berpe- ngaruh negatif terhadap $\mathrm{Y}$ atau $\mathrm{X}_{2}$ tidak berpengaruh negatif terhadap Y. Sedangkan jika -t hitung $<-t$ tabel, maka $\mathrm{H}_{0}$ ditolak, artinya variabel $X_{1}$ berpengaruh negatif terhadap $\mathrm{Y}$ atau $\mathrm{X}_{2}$ berpengaruh negatif terhadap $Y$. Hasil perhitungan Uji $T$ dengan menggunakan SPSS sebagai berikut:

Tabel 3. Uji T

\begin{tabular}{|c|c|c|c|c|c|c|}
\hline & \multirow[t]{2}{*}{ Model } & \multicolumn{2}{|c|}{$\begin{array}{l}\text { Unstandardized } \\
\text { Coefficients }\end{array}$} & \multirow{2}{*}{$\begin{array}{c}\text { Standardized } \\
\text { Coefficients } \\
\text { Beta }\end{array}$} & \multirow[t]{2}{*}{ T } & \multirow[t]{2}{*}{ Sig. } \\
\hline & & B & Std. Error & & & \\
\hline \multirow[t]{3}{*}{1} & (Constant) & 122,353 & 13,717 & & 8,920 & ,000 \\
\hline & Keterlibatan Kerja &,- 561 & ,078 &,- 665 & $-7,233$ &, 000 \\
\hline & Kepuasan Kerja &,- 198 & 080 &,- 227 & $-2,468$ &, 000 \\
\hline
\end{tabular}

Berdasarkan hasil perhitungan di atas, diperoleh thitung untuk keterlibatan kerja sebesar -7,233 dan thitung untuk kepuasan kerja sebesar $-2,468$. Sedangkan besarnya tabel dapat dicari pada tabel staitistik signifikasi $5 \%$ atau 0,05 dengan $\mathrm{df}=\mathrm{n}-\mathrm{k}$ atau 68-3 $=65$, maka diperoleh tabel sebesar 1,670. Dengan demikian, dapat diketahui bahwa -thitung dari keterlibatan kerja $-7,233<-$ ttabel yaitu $-1,670$, maka $\mathrm{H}_{0}$ ditolak, sehingga dapat diambil kesimpulan bahwa keterlibatan kerja mempunyai pengaruh negatif yang signifikan terhadap keinginan berpindah. Kemudian, dapat diketahui bahwa -thitung dari kepuasan kerja $-2,468<-t_{\text {tabel }}$ yaitu $-1,670$, maka $\mathrm{H}_{0}$ ditolak, sehingga dapat diambil kesimpulan bahwa kepuasan kerja mempunyai pengaruh negatif yang signifikan terhadap keinginan berpindah. 
Analisis koefisien determinasi $\left(R^{2}\right)$ digunakan untuk mengetahui seberapa besar presentase sumbangan pengaruh variabel independen, yaitu keterlibatan kerja dan kepuasan kerja secara serentak terhadap variabel dependen yaitu keinginan berpindah. Berikut hasil perhitungan koefisien determinasi menggunakan SPSS.

Tabel 4. Koefisien Determinasi

\begin{tabular}{|ccccc|}
\hline Model & $\mathrm{R}$ & $\mathrm{R}$ Square & Adjusted R Square & $\begin{array}{c}\text { Std. Error of the } \\
\text { Estimate }\end{array}$ \\
\hline 1 &, $677^{\mathrm{a}}$ &, 458 &, 441 & 6,738 \\
\hline
\end{tabular}

Berdasarkan tabel di atas, dapat diketahui bahwa nilai $\mathrm{R}^{2}$ sebesar 0,458. Jadi, kemampuan dari variabel keterlibatan kerja dan kepuasan kerja untuk menjelaskan keinginan berpindah secara stimulan yaitu $45,8 \%$ sedangkan sisanya $54,2 \%$ dipengaruhi oleh faktor lain yang tidak diteliti. Untuk mengukur derajat hubungan antar variabel keterlibatan kerja (X1) dan kepuasan kerja (X2) terhadap keinginan berpindah $(Y)$ dapat melihat nilai $R$ yang ada pada tabel 4 yaitu sebesar 0,677 berarti nilai $R$ termasuk kategori $(0,60-0,79)$, maka keeratan hubungan antara keterlibatan kerja dan kepuasan kerja terhadap keinginan berpindah tergolong kuat.

Berdasarkan hasil penelitian regresi berganda, keterlibatan kerja dan kepuasan kerja secara bersama-sama berpengaruh terhadap keinginan berpindah dengan koefisien determinasi $\left(R^{2}\right)$ sebesar 0,458 . Artinya, pengaruh variabel independen yaitu keterlibatan kerja dan kepuasan kerja terhadap variabel dependen yaitu keinginan berpindah sebesar $45,8 \%$. Sedang- kan sisanya $54,2 \%$ dipengaruhi oleh faktor lain yang tidak diteliti.

Kemudian, berdasarkan hasil uji hipotesis, kedua variabel bebas yaitu keterlibatan kerja dan kepuasan kerja secara serentak memiliki pengaruh terhadap keinginan berpindah dengan $F_{\text {hitung }}>\mathrm{F}_{\text {tabel, }}$ yaitu sebesar 27,442>3,14, sehingga dapat disimpulkan keterlibatan kerja dan kepuasan kerja secara serentak berpengaruh terhadap keinginan berpindah.

Selanjutnya, berdasarkan hasil perhitungan yang telah dilakukan, maka dapat diinterpretasikan bahwa keterlibatan kerja mempengaruhi keinginan berpindah, artinya semakin tinggi keterlibatan kerja yang diterapkan oleh karyawan, maka semakin rendah keinginan berpindah yang dirasakan oleh karyawan. Selain itu, kepuasan kerja juga mempengaruhi keinginan berpindah, yaitu semakin tinggi kepuasan kerja, maka semakin rendah keinginan berpindah pada karyawan.

Demikian pula sebaliknya, semakin rendah keterlibatan kerja 
yang diterapkan oleh karyawan, maka semakin tinggi pula keinginan berpindah yang dirasakan oleh karyawan. Kemudian, semakin rendah kepuasan kerja, maka semakin tinggi pula keinginan berpindah pada karyawan.

\section{KESIMPULAN}

Berdasarkan hasil penelitian tentang pengaruh keterlibatan kerja dan kepuasan kerja terhadap keinginan berpindah (turnover intention) pada karyawan, maka dapat disimpulkan bahwa:

1. Terdapat pengaruh yang signifikan antara keterlibatan kerja dan kepuasan kerja terhadap keinginan berpindah dengan nilai $F_{\text {hitung }}>F_{\text {tabel, }}$ yaitu sebesar 27,442 > 3,14. Artinya, jika keterlibatan kerja dan kepuasan kerja tinggi, maka keinginan berpindah pada karyawan akan rendah. Begitupula sebaliknya, jika keterlibatan kerja dan kepuasan kerja rendah, maka keinginan berpindah pada karyawan akan tinggi.

2. Terdapat pengaruh negatif yang signifikan antara keterlibatan kerja dan keinginan berpindah dengan nilai thitung untuk keterlibatan kerja sebesar $\quad-7,233<$ $-1,670$ ttabel. Artinya, jika keterlibatan kerja tinggi maka keinginan berpindah akan rendah, dan sebaliknya jika keterlibatan kerja rendah maka keinginan berpindah akan tinggi.

3. Terdapat pengaruh negatif yang signifikan antara kepuasan kerja dan keinginan berpindah dengan nilai thitung untuk kepuasan kerja sebesar $-2,468<-1,670$ tabel. Artinya, jika kepuasan kerja tinggi maka keinginan berpindah akan rendah, dan sebaliknya jika kepuasan kerja rendah maka keinginan berpindah akan tinggi.

4. Berdasarkan uji koefisien determinasi, dapat disimpulkan bahwa kontribusi yang diberikan oleh variabel keterlibatan kerja dan kepuasan kerja terhadap keinginan berpindah yaitu sebesar $45,8 \%$, sedangkan sisanya sebesar $54,2 \%$ dipengaruhi oleh faktor lain yang tidak diteliti.

\section{DAFTAR PUSTAKA}

Anwar, S. (2000). Sikap Manusia: Teori dan Pengukurannya. Yogyakarta: Pusataka Pelajar.

Arianto, T. A. (2001). Analisis faktor-faktor yang mempengaruhi turnover intentions pada staff kantor akuntan publik. . Jurnal Akuntansi \& Keuangan, 3.

Arifuddin, S. A. (2002). Analisis Pengaruh Komitmen Organisasi dan Keterlibatan kerja terha-dap Hubungan antara Etika Kerja Islam dengan Sikap Perubahan Organisasi. Jurnal Akuntansi dan Auditing Indonesia, 162.

Cristian, D. (2005). Concflict Stress and Well-Being at Work: The Ruffering Effect of Third - 
Party Help. European Journal of work and organizational Phycshology, 140.

Faslah, R. (2010). Hubungan Antara Keterlibatan Kerja Dengan Turnover Intention Pada Karyawan PT. Garda Trimitra Utam. Jurnal Online Ekonomi Dan Pendidikan, 2.

Habibullah, J. (2011). Kepuasan Kerja, Komitmen Organisasi dan Intensi Turnover. Bisnis dan Manajemen (Vol. 2).

Hanafiah, M. (2014). Pengaruh Kepuasan Kerja dan Job Insecurity Karyawan terhadap Intensi Turnover PT. Buma Desa Berau. Surabaya: Damandiri Online Jurnal Psikologi.

Handoko, T. H. (2011). Manajemen Personalia dan Sumber Daya Manusia. Yogyakarta: BPFE.

Istijanto. (2005). Riset Sumber Daya Manusia. Jakarta : PT. Grame-dia Pustaka Utama.

Ivancevich et, a. (2006). Perilaku dan Manajemen Organisasi. Jakarta: Erlangga.

Jackson, M. R. (2001). Manajemen Sumber Daya Manusia. Jakarta: Salemba Empat.

Januarti, I. d. (2006). Pengaruh Komitmen Organisasional dan Keterlibatan Kerja terhadap Hubungan antara Etika Kerja Islam dengan Sikap terhadap Perubahan Organisasi. Jurnal
Akuntansi dan Auditing Indonesia, 20.

Js, F. P. (2004). Hubungan Keadilan dan Kepu-asan dengan Keinginan Berpin-dah: Peran Komitmen Organi-sasional Sebagai Variabel Pemediasi, Fe Universitas Bengkulu (Vol. 9). Bengkulu : FE Universitas Bengkulu .

Judge, R. S. (2008). Perilaku Organi-sasi. Jakarta : Salemba Empat .

Judge, R. S. (2008). Perilaku Organi-sasi. Jakarta: Salemba Empat.

Kusuma, R. V. (2002). Pengaruh Job Insecurity, Faktor Anteseden, dan Konsekuensinya terhadap Keinginan Berpindah Karya-wan: Studi Empiris pada Kantor Akuntan Publik di Indonesia,. Jurnal Riset Akuntansi Indonesia, 5.

Liu, H.-W. L.-H. (2007). An Examination of Factors Affecting Repatries' Turnover Intention. Internati-onal Journal of Manpower, 28.

Mandasari, D. F. (2011). FaktorFaktor Psikologis sebagai Anteseden Kepuasan Kerja Auditor Junior dan Dampaknya Terhadap Intensitas Turnover: Studi Empiris pada Kantor Akuntan Publik Se-Sulawesi,. Jurnal Ekonomi dan Bisnis, 2, 8. 
Muafi, S. Y. (2008). Turnover Intention: Faktor-Faktor yang Mempengaruhi-nya, Manajemen Usahawan Indonesia.

Quick, N. D.-b. (2011). Organizational Behaviour: Science The Real World and You. Mason: South- Western Cengage Learning.

Rivai, V. (2005). Manajemen Sumber Daya Manusia dari Teori ke Praktek. Jakarta: PT. Raja Grafindo Persada.

Rivai, V. (2012). Kepemimpinan dan Perilaku Organisasi,. Jakarta: Raja Grafindo Persada.

Robbins, S. P.-t. (2007). Manajemen. Jakarta: PT. Index Group Gramedia.

Saidi, W. d. (2007). Manajemen Sumber Daya Manusia. Jakarta : Unit Layanan Psikologi PKMT Press.

Simanjuntak. (2013). Analisis Pengruh Keterlibatan Kerja dan Kepu-asan Kerja terhadap Turnover Intention karyawan (studi pada PT. Njonja Meneer Semarang. Journal Management, 2, 2.

Sinambela, L. P. (2012). Kinerja Pegawai, Teori Pengu-kuran dan Implikasi. Yogyakarta: Graha Ilmu .

Sondang, S. (2008). Majamen Sumber Daya Manusia. Jakarta : PT Bumi Aksara.

Sopiah. (2008). Perilaku Organisasional. Yogyakarta: ANDI.

Sugiyono. (2006). Metode Penelitian Pendidikan. Bandung: Alfabeta.

Sulistyawati. (2008). Dyah Analisis Pengaruh Komitmen Organisasi Terhadap Keinginan Berpindah pada Dosen Tetap Fakultas Untar di Jakarta. Jurnal Manajemen, 45.

West, S. A. (2010). he Psycho-logy of work and Organi-zations. Canada: Cengage Learning. 
Available at:

http://journal.unj.ac.id/unj/index.php/econosains/article/view/1653 